University of Michigan Law School

University of Michigan Law School Scholarship Repository

\title{
Civil Rights, Access to Counsel, and Injunctive Class Actions in the United States
}

Maureen Carroll

University of Michigan Law School, msclaw@umich.edu

Available at: https://repository.law.umich.edu/book_chapters/154

Follow this and additional works at: https://repository.law.umich.edu/book_chapters

Part of the Civil Procedure Commons, Legal Profession Commons, and the Litigation Commons

\section{Publication Information \& Recommended Citation}

Carroll, Maureen. "Civil Rights, Access to Counsel, and Injunctive Class Actions in the United States." In The Cambridge Handbook of Class Actions: An International Survey, edited by Brian Fitzpatrick and Randall Thomas, 25-38. Cambridge: Cambridge University Press, 2021.

This Book Chapter is brought to you for free and open access by the Faculty Scholarship at University of Michigan Law School Scholarship Repository. It has been accepted for inclusion in Book Chapters by an authorized administrator of University of Michigan Law School Scholarship Repository. For more information, please contact mlaw.repository@umich.edu. 


\title{
Civil Rights, Access to Counsel, and Injunctive Class Actions in the United States
}

\author{
Maureen Carroll
}

\subsection{INTRODUCTION}

According to a familiar story about class actions in the United States, aggregation promotes access to counsel by increasing the amount of money from which counsel fees can be taken. ${ }^{1}$ Courts usually award class counsel a percentage of the monetary recovery obtained on behalf of the class, ${ }^{2}$ and class treatment can turn a $\$ 30$ case into a $\$ 3$ million case. But what about class actions that do not involve monetary relief at all?

Some civil rights plaintiffs seek to stop a violation, rather than to obtain compensation for past harm, and therefore choose to pursue only an injunction or declaratory judgment. Other civil rights plaintiffs have no choice but to pursue only injunctive or declaratory relief, for reasons ranging from statutory constraints to immunity doctrines. ${ }^{3}$ Unlike in aggregated-damages cases, class treatment in injunction-only cases does not have a multiplicative effect that makes the litigation more lucrative - and thus more attractive - from a law firm's perspective. ${ }^{4}$ Indeed, one might expect that the prospect of class certification would decrease access to counsel in such cases, because federally funded legal aid organizations are prohibited from working on class actions. $^{5}$

1 The United States Supreme Court has referred to this access-promoting effect as "[t]he policy at the very core of the class action mechanism.” Amchem Prod., Inc. v. Windsor, 521 U.S. 591, 617 (1997) (quoting Mace v. Van Ru Credit Corp., 109 F.3d 338, 344 (7th Cir. 1997)).

2 See infra Section 2.3 .

3 See, e.g., Harlow v. Fitzgerald, 457 U.S. 800 (1982) (holding that that qualified immunity limits a plaintiffs ability to recover monetary damages from government officials); Edelman v. Jordan, 415 U.S. 651 (1974) (holding that the Eleventh Amendment limits a plaintiffs ability to recover monetary relief from state defendants); Samuel R. Bagenstos, The Perversity of Limited Civil Rights Remedies: The Case of "Abusive" ADA Litigation, 54 UCLA L. REv. 1, 2 (2006) (noting that the public accommodations title of the Americans with Disabilities Act of 1990 does not authorize private plaintiffs to seek damages).

4 Class treatment might increase the remedial cost to the defendant in an injunction-only case, but it might not. See Maureen Carroll, Class Action Myopia, 65 Duke L.J. 843, 866-68 (2016). In any event, the counsel fee in an injunction-only case will not generally increase in proportion to the defendant's remedial cost. See infra Section 2.3.

5 See 45 C.F.R. \& 1617.3 (prohibiting recipients of federal Legal Services Corporation funding from "initiating or participating in any class action”); see also Velazquez v. Legal Servs. Corp., 164 F.3d 757 (2d Cir. 1999), affd, 531 U.S. 533 (2001) (rejecting statutory and constitutional challenges to this restriction). This restriction applies at the entity level, such that any legal organization that receives LSC funding cannot work on a class action even if it uses non-LSC funds to do so. An LSC-funded organization can coordinate its activities with an affiliate that does work on class actions (or engages in other restricted activities), but only if it maintains legal, physical, and financial separation from any such affiliate. See 45 C.F.R. $\int 1610.7$. As a result, "[i]n many states, justice planners have had to set up two, duplicative legal aid systems in order to ensure that state and other funds are not constrained by the non-LSC funds 
This chapter will explore the relationship between class treatment and access to counsel in injunction-only civil rights cases. It will demonstrate that class certification does promote access to counsel in such cases, but through a different set of mechanisms than those at play when a plaintiff class seeks monetary relief. Broadly speaking, while aggregated-damages class actions can attract counsel through the prospect of money-making, ${ }^{6}$ injunction-only class actions can attract counsel through the prospect of resource-leveraging. ${ }^{7}$

Through its effects on areas ranging from justiciability to remedial scope, the injunctive class action offers a resource-constrained legal organization the prospect of broadening its impact without a commensurate increase in spending. Accordingly, class treatment can both increase the attractiveness of taking on the representation and expand the group of claimants served by the representation that takes place.

\subsection{A BRIEF HISTORY OF RULE 23}

This section provides an overview of the federal class action rule, from its initial adoption several decades ago to the role it plays in aggregate litigation today. Scholars have traced the roots of the American class action back to medieval times. ${ }^{8}$ For a briefer history, the year 1934 provides a useful entry point.

\subsubsection{The Federal Rules of Civil Procedure}

In 1934, Congress gave the United States Supreme Court "the power to prescribe general rules of practice and procedure" for cases heard in the federal court system. ${ }^{9}$ The Court, in turn, appointed an Advisory Committee of attorneys and academics responsible for drafting those procedures (and, subsequently, for amending them as needed). ${ }^{10}$

The Advisory Committee's initial work resulted in the adoption, in 1938, of a single set of procedural rules to govern civil lawsuits in federal district courts. ${ }^{11}$ The Federal Rules of Civil Procedure remain in place today, though they have been amended multiple times. The Federal Rules do not directly apply to the independent court systems run by each state, but over time, most states have adopted procedural rules modeled after them. ${ }^{12}$

restriction." Rebekah Diller \& Emily Savner, Restoring Legal Aid for the Poor: A Call to End Draconian and Wasteful Restrictions, 36 Fordham URB. L.J. 687, 689 (2009).

6 See infra Section 2.3. 7 See infra Section 2.4.

8 See generally Stephen C. Yeazell, From Medieval Group Litigation to the Modern Class Action (1987); Robert G. Bone, Personal and Impersonal Litigative Forms: Reconceiving the History of Adjudicative Representation, 70 B.U. L. Rev. 213 (1990).

9 See 28 U.S.C. $\$ 2072(a)$ ("The Supreme Court shall have the power to prescribe general rules of practice and procedure and rules of evidence for cases in the United States district courts (including proceedings before magistrate judges thereof) and courts of appeals.").

10 See Brooke D. Coleman, \#SoWhiteMale: Federal Civil Rulemaking, 113 Nw. U. L. REV. 407, 411-12 (2018). Currently, "there are more judges and fewer academics on the Committee, flipping the original composition of solely practitioners and professors.” Id. at 412.

${ }^{11}$ See Fed. R. Civ. P. I (stating that, with limited exceptions, "[t]hese rules govern the procedure in all civil actions and proceedings in the United States district courts").

12 See John B. Oakley \& Arthur F. Coon, The Federal Rules in State Courts: A Survey of State Court Systems of Civil Procedure, 61 WASH. L. REV. 1367, 1369 (1986) (noting "the pervasive influence of the Federal Rules on at least some part of every state's civil procedure”). But see John B. Oakley, A Fresh Look at the Federal Rules in State Courts, 3 NEV. L.J. 354, 355 (2003) ("Not only has the trend toward state conformity to the federal rules stopped accelerating - it has substantially reversed itself."). 
Rule 23 of the Federal Rules of Civil Procedure governs class actions, setting forth conditions under which one or more members of a class can sue or be sued "on behalf of all." "I In the original version of the rule, class certification required that "the right sought to be enforced for or against the class" must fit into one of three categories. ${ }^{14}$ The binding effect of the judgment depended on which of those three categories applied: in "true" and "hybrid" class actions the judgment bound the entire class, while in "spurious" class actions it bound only the named parties (including intervenors). ${ }^{15}$

Courts and litigants struggled to understand the "obscure and uncertain" terminology in the 1938 version of the rule. ${ }^{16}$ In addition, some objected to the "one-way" intervention prevalent in spurious class actions, in which courts essentially allowed claimants to wait for a decision on the merits before deciding whether they would join the class. ${ }^{17}$ The rule was widely understood to be a failed effort, eventually prompting the Advisory Committee to consider significant reforms. ${ }^{18}$

\subsubsection{The 1966 Amendments}

Rule 23 took on its modern structure through an extensive set of amendments that went into effect in 1966. ${ }^{19}$ Under the modern version of the rule, each class action must satisfy a set of four prerequisites: numerosity, ${ }^{20}$ commonality, ${ }^{21}$ typicality, ${ }^{22}$ and adequacy of representation. ${ }^{23}$ Each class action must also fall into one of four categories, which are set forth in Rule 23 (b). ${ }^{24}$

The modern version of Rule 23 is transsubstantive, meaning that it is "written to apply broadly regardless of the nature of the underlying substantive claim." 25 At the same time, the drafters of the 1966 amendments intended for the rule to facilitate effective remedies in civil rights litigation. ${ }^{26}$ That intent found expression in Rule $23(\mathrm{~b})(2)$, which applies when "the party

13 Fed. R. Civ. P. 23 (a).

14 Specifically, the $193^{8}$ version of the rule required the right to be

(1) joint, or common, or secondary in the sense that the owner of a primary right refuses to enforce that right and a member of the class thereby becomes entitled to enforce it;

(2) several, and the object of the action is the adjudication of claims which do or may affect specific property involved in the action; or

(3) several, and there is a common question of law or fact affecting the several rights and common relief is sought.

Fed. R. Civ. P. 23 (a) (1938).

15 Fed. R. Civ. P. 23 - Advisory Committee Note to 1966 Amendments. $\quad{ }^{16}$ Id.

${ }_{17}$ See Benjamin Kaplan, Continuing Work of the Civil Committee: 1966 Amendments of the Federal Rules of Civil Procedure, 81 Harv. L. Rev. 356, 385 (1967).

18 See David Marcus, The History of the Modern Class Action, Part I: Sturm Und Drang, 1953-1980, 90 WASH. U.L. REV. 587, 600-01 (2013).

19 See Maureen Carroll, Class Action Myopia, 65 Duke L.J. 843, 852 (2016); David Marcus, The History of the Modern Class Action, Part I: Sturm Und Drang, 1953-1980, 90 WASH. U.L. Rev. 587, 588 (2013).

20 Fed. R. Civ. P. 23 (a)(1) ("the class is so numerous that joinder of all members is impracticable").

${ }^{21}$ Fed. R. Civ. P. 23 (a)(2) ("there are questions of law or fact common to the class").

22 Fed. R. Civ. P. 23(a)(3) ("the claims or defenses of the representative parties are typical of the claims or defenses of the class").

23 Fed. R. Civ. P. $23(\mathrm{a})(4)$ ("the representative parties will fairly and adequately protect the interests of the class").

24 Two of these categories are discussed infra notes 26-32 and accompanying text. The others, which appear in Rule $23(\mathrm{~b})(\mathrm{1})(\mathrm{A})$ and (B), apply in a much narrower set of situations and are seldom used. See generally Robert H. Klonoff, Class Actions for Monetary Relief Under Rule 23(b)(1)(A) and (b)(1)(B): Does Due Process Require Notice and Opt-Out Rights?, 82 Geo. Wash. L. Rev. 798 (2014) (discussing the history and scope of these provisions).

25 Robert G. Bone, Walking the Class Action Maze: Toward A More Functional Rule 23, 46 U. Mich. J.L. Reform 1097,1123 (2013).

26 See David Marcus, Flawed but Noble: Desegregation Litigation and Its Implications for the Modern Class Action, 63 FLA. L. REV. 657, 702-08 (2011); see also infra Section 2.4. 
opposing the class has acted or refused to act on grounds that apply generally to the class, so that final injunctive relief or corresponding declaratory relief is appropriate respecting the class as a whole." ${ }^{27}$ In the notes it published alongside the 1966 amendments, the Advisory Committee wrote that "[i]llustrative" of situations falling under Rule $23(\mathrm{~b})(2)$ were "various actions in the civil-rights field where a party is charged with discriminating unlawfully against a class." 28

Rule $23(\mathrm{~b})(2)$ thus had its genesis in an existing (if recent) type of aggregate litigation. By contrast, Rule 23(b)(3) was "a new category deliberately created," as its principal author described it. ${ }^{29}$ Rule 23(b)(3) applies when "questions of law or fact common to class members predominate over any questions affecting only individual members" (the predominance requirement), and "a class action is superior to other available methods for fairly and efficiently adjudicating the controversy" (the superiority requirement)..$^{30}$ Although the text of Rule $23(\mathrm{~b})(3)$ does not refer to the remedies that class members may seek, its primary purpose and effect is to allow the aggregation of claims for monetary relief.

Regardless of which category of Rule 23 (b) applies, the judgment in a certified class action binds every member of the class, regardless of the outcome. ${ }^{31}$ Moreover, everyone who falls within the class definition is a member of the class by default; opting in is not required. Members of classes certified under Rule $23(\mathrm{~b})(3)$, however, must be given the chance to opt out. ${ }^{22}$

\subsubsection{Modern Class-Action Practice}

Hundreds of putative class actions are filed in the federal courts each month. ${ }^{33}$ Due in part to the financial incentives at play, ${ }^{34}$ a large majority of these cases involve aggregated-damages class actions. ${ }^{35}$ Indeed, when most people in the United States think of class actions, claims for monetary relief are surely the ones that come to mind..$^{36}$

Injunction-only class actions, however, continue to be certified, and they continue to play an important role in civil rights litigation. For example, federal courts have recently certified injunction-only class actions in cases involving family separation at the border, ${ }^{37}$ the education of children with disabilities, ${ }^{38}$ the health and safety of children in foster care, ${ }^{39}$ medical care for incarcerated persons, ${ }^{40}$ and the reproductive rights of immigrant detainees,${ }^{41}$ to name just a few.

27 Fed. R. Civ. P. 23(b)(2). With regard to the phrase "corresponding declaratory relief," the Advisory Committee explained that "[d]eclaratory relief "corresponds' to injunctive relief when as a practical matter it affords injunctive relief or serves as a basis for later injunctive relief.” Fed. R. Civ. P. 23 - Advisory Committee Note to 1966 Amendments.

28 Fed. R. Civ. P. 23 - Advisory Committee Note to 1966 Amendments.

29 Benjamin Kaplan, Continuing Work of the Civil Committee: 1966 Amendments of the Federal Rules of Civil Procedure, 81 Harv. L. Rev. 356, 399 (1967).

30 Fed. R. Civ. P. $23($ b) (3).

${ }^{31}$ See Fed. R. Civ. P. 23 - Advisory Committee Notes to 1966 Amendments ("all class actions maintained to the end as such will result in judgments including those whom the court finds to be members of the class, whether or not the judgment is favorable to the class").

32 Fed. R. Civ. P. $23(\mathrm{c})(2)(\mathrm{B})$. The rule does not require courts to afford members of other categories of class actions the chance to opt out. Fed. R. Civ. P. $23(\mathrm{c})(2)(\mathrm{A})$.

33 See Emery G. Lee III \& Thomas E. Willging, The Impact of the Class Action Fairness Act on the Federal Courts: An Empirical Analysis of Filings and Removals, 156 U. PA. L. REV. 1723, 1751 (2008). Nearly all class actions involve the aggregation of plaintiffs, rather than defendants. Thomas E. Willging, Laural L. Hooper, \& Robert J. Niemic, An Empirical Analysis of Rule 23 to Address the Rulemaking Challenges, 71 N.Y.U. L. REv. 74, 119-20 (1996).

34 See infra Section 2.3. $\quad 35$ See Maureen Carroll, Class Action Myopia, 65 Duke L.J. 843, 849 \& n.27 (2016).

$3^{6}$ Cf. id. at 870 (characterizing modern debates about class actions).

37 See Ms. L. v. U.S Immigration \& Customs Enft, 330 F.R.D. 284 (S.D. Cal. 2019).

$3^{8}$ DL v. D.C., 860 F.3d 713 (D.C. Cir. 2017). 39 B.K. v. Snyder, 922 F.3d 957 (9th Cir. 2019).

40 Braggs v. Dunn, 317 F.R.D. 634 (M.D. Ala. 2016). ${ }^{41} \quad$ J.D. v. Azar, 925 F.3d 1291 (D.C. Cir. 2019). 


\subsection{AGGREGATION AND MONEY-MAKING}

This section discusses the relationship between class treatment and counsel profit. In particular, it explains why aggregated-damages class actions can often harness law firms' profit motives in ways that injunction-only class actions cannot.

Two things bear noting at the outset. First, federal courts in the United States follow the American Rule, which creates a default expectation that every litigant will pay for its own counsel fees. ${ }^{4^{2}}$ Second, a class lacks the capacity to enter into a fee agreement with class counsel. A class is merely a group of persons whose claims share certain characteristics; it has no internal governance or decision-making structure. ${ }^{43}$ Accordingly, although individual class members can make binding commitments without judicial involvement or review, the class as a whole cannot. Instead, the court must determine whether and how much class counsel will be paid. ${ }^{44}$

\subsubsection{Common-Fund Awards}

The common-fund doctrine provides that "a litigant or a lawyer who recovers a common fund for the benefit of persons other than himself or his client is entitled to a reasonable attorney's fee from the fund as a whole." 45 As the Supreme Court has explained, this equitable doctrine "rests on the perception that persons who obtain the benefit of a lawsuit without contributing to its cost are unjustly enriched at the successful litigant's expense." ${ }^{6}$

Although the doctrine predates the modern class action, most common-fund cases now involve the compensation of class counsel. ${ }^{47}$ The common-fund doctrine translates neatly to the context of class actions for monetary relief; if a court were to permit absent class members to keep the entirety of a fund recovered on their behalf, they would be unjustly enriched at class counsel's expense..$^{8}$

In aggregated-damages class actions, courts usually grant class counsel a percentage of the monetary relief as a common-fund award. ${ }^{49}$ In injunction-only class actions, however, there is no monetary recovery from which to take payment - no "fund" from which to take a common-fund award. Because the common-fund doctrine does not apply, it cannot create a financial incentive for a law firm to seek class treatment in an injunction-only case.

\subsubsection{Fee-Shifting Awards}

By congressional design, the enforcement of public law in the United States is heavily dependent on private litigation. For example, individuals file roughly 15,000 employment discrimination lawsuits every year, while the relevant agency files only a few hundred..$^{\circ}$ This reliance on private

$4^{2}$ By contrast, "in most Western legal systems other than the United States, the prevailing norm is the English rule, which provides that the losing party must pay the winner's reasonable fees." Theodore Eisenberg \& Geoffrey P. Miller, The English Versus the American Rule on Attorney Fees: An Empirical Study of Public Company Contracts, 98 Cornell L. Rev. 327, 329 (2013).

43 See generally Samuel Issacharoff, The Governance Problem in Aggregate Litigation, 81 Fordham L. Rev. 3165 (2013).

44 See Fed. R. Civ. P. 23(h) (setting forth procedures by which "the court may award reasonable attorney's fees and nontaxable costs that are authorized by law or by the parties' agreement”).

45 Boeing Co. v. Van Gemert, 444 U.S. 472, 478 (1980). ${ }^{46}$ Id.

47 William B. Rubenstein, 5 Newberg on Class Actions \ 15:53 (5th ed. 2019).

$4^{8}$ See Charles Silver, A Restitutionary Theory of Attorneys' Fees in Class Actions, 76 Cornell L. Rev. 656, 713 (1991).

49 See Brian T. Fitzpatrick, An Empirical Study of Class Action Settlements and Their Fee Awards, 7 J. EmPIRICAL LEGAL STUd. 811, 832 (2010); Theodore Eisenberg \& Geoffrey P. Miller, Attorney Fees and Expenses in Class Action Settlements: 1993-2008, 7 J. Empirical Legal STud. 248, 267-68 (2010).

50 See David Freeman Engstrom, Agencies As Litigation Gatekeepers, 123 YALE L.J. 616, 689 \& n.242 (2013). 
litigants, rather than government officials, untethers enforcement activity from the constraints imposed by agency budgets and presidential priorities..$^{51}$

Due to the important role they play in the overall enforcement regime, plaintiffs who sue to enforce civil rights laws are sometimes called "private attorneys general." $5^{2}$ Many claimants cannot afford to pay their attorneys out of pocket, however, and the contingent percentage fee - like the common-fund doctrine - can facilitate representation only in cases that involve monetary relief.

Claims for injunctive or declaratory relief can thus fall into a gap in the market for legal services, and because many civil rights plaintiffs seek only injunctive or declaratory relief, ${ }^{53}$ this market gap has the potential to stymie civil rights enforcement. In an effort to prevent that result, Congress has enacted a set of fee-shifting statutes, which allow a prevailing plaintiff to recover a reasonable attorney's fee from the defendant in specified types of cases. ${ }^{54}$

Even in those specified cases, however, fee-shifting statutes do not create a financial incentive for counsel to bring injunction-only class actions. Consider a case seeking an injunction against a state statute. If the lawsuit causes the state to repeal the statute before a court has enjoined its enforcement, the plaintiffs will usually not be deemed eligible for a court-ordered fee. ${ }^{55}$ This type of "strategic capitulation" can deprive counsel of fees in both class and nonclass actions. ${ }^{56}$

Alternatively, consider a case in which the defendant offers to provide all of the injunctive relief requested, but only if the plaintiffs will waive their entitlement to a fee-shifting award. ${ }^{57}$ This type of "sacrifice offer" can occur in either a class or a nonclass action, ${ }^{5}$ but in a nonclass case, retainer agreements and client choices can blunt its impact or lead to its rejection. ${ }^{59}$ In a class action, however, retainer agreements do not bind the class, and class counsel must decide whether to accept or reject a settlement offer on the absent class members' behalf. ${ }^{60}$ Class counsel might deem themselves obligated to accept a sacrifice offer, and as a result, they might receive no compensation for their work on the case. ${ }^{61}$

When courts do issue statutory fee-shifting awards, the amounts are structurally undercompensatory in both class and nonclass cases. Fee-shifting awards are not based on the number of individuals whose rights were vindicated. ${ }^{62}$ Instead, courts calculate fee-shifting awards using the lodestar method, which multiplies each attorney's reasonable hourly rate by the number of hours the attorney reasonably spent on the litigation. ${ }^{63}$ Although courts will order a fee shift only

51 See generally Sean Farhang, The Litigation State (2010).

52 See, e.g., Newman v. Piggie Park Enterprises, Inc., 390 U.S. 400, 402 (1968) ("If [a civil rights plaintiff] obtains an injunction, he does so not for himself alone but also as a 'private attorney general,' vindicating a policy that Congress considered of the highest priority.").

53 See supra note 3 and accompanying text.

54 See, e.g., 42 U.S.C. $\$ 1988$ ("In any action or proceeding to enforce a provision of ... title VI of the Civil Rights Act of $1964 \ldots$ the court, in its discretion, may allow the prevailing party ... a reasonable attorney's fee as part of the costs").

55 See Buckhannon Bd. \& Care Home, Inc. v. W. Va. Dep't of Health \& Human Res., 532 U.S. 598 (2001); see also Maureen Carroll, Fee-Shifting Statutes and Compensation for Risk, 95 Indiana L.J. 1021, 1030 nn. 54-56 (2020) (discussing caveats and exceptions).

56 Catherine R. Albiston \& Laura Beth Nielsen, The Procedural Attack on Civil Rights: The Empirical Reality of Buckhannon for the Private Attorney General, 54 UCLA L. REv. 1087, 1091 (2007).

57 See Evans v. Jeff D., 475 U.S. 717 (1986).

58 See David Luban, Taking Out the Adversary: The Assault on Progressive Public-Interest Lawyers, 91 CaL. L. Rev. 209, 241 (2003).

59 See Maureen Carroll, Fee-Shifting Statutes and Compensation for Risk, 95 Indiana L.J. 1021, 1030 (2020).

6o After class counsel makes this initial decision, the court must review the settlement to ensure that it is "fair, reasonable, and adequate" as to any class members who would be bound by it. See Fed. R. Civ. P. 23(e)(2).

${ }_{61}$ This sequence of events occurred in Evans v. Jeff D., 475 U.S. 717 (1986).

62 See Maureen Carroll, Aggregation for Me, but Not for Thee: The Rise of Common Claims in Non-Class Litigation, 36 Cardozo L. Rev. 2017, 2073-74 \& n.324 (2015).

63 See Hensley v. Eckerhart, 461 U.S. 424 (1983). 
if the plaintiff prevails, and the lodestar uses noncontingent hourly rates, courts will not adjust the lodestar amount to reflect the counsel's risk of nonpayment. ${ }^{64}$

Class treatment does not fundamentally alter the under-compensatory effects of denying compensation for risk. ${ }^{6}$ On the one hand, seeking class certification will usually require class counsel to do additional work (as compared to a single, nonclass case), which will drive up the hours-worked component of the lodestar. On the other hand, the absence of risk enhancement means that, rather than devoting time to seeking class certification in a fee-shifting case, a profitmotivated attorney would do better to spend that time on a case paid via hourly billing. ${ }^{66}$

\subsection{AGGREGATION AND RESOURCE-LEVERAGING}

Under the compensation systems discussed above, a law firm will not usually have a profit motive to seek class treatment in an injunction-only case. ${ }^{67}$ Moreover, a nonprofit law firm that receives federal legal aid funding cannot bring a class action, regardless of the type of relief sought. ${ }^{68}$ Why, then, would any law firm bring a class action on behalf of plaintiffs seeking only injunctive relief?

A significant number of law firms in the United States exist to serve their vision of the public interest, ${ }^{69}$ rather than to make a profit, and the bulk of these firms do not receive federal legal aid funding. ${ }^{70}$ Instead, these public interest law organizations (PILOs) rely on private grants and contributions, among other funding sources. ${ }^{71}$ Money is perpetually in short supply, and despite paying dramatically below-market salaries and taking other steps to keep costs down, a PILO generally cannot afford to take on all of the cases that would further its organizational mission. ${ }^{72}$ As this section explains, a class action offers this type of firm the potential for preserving and amplifying the effects of the resources it expends on a particular case.

\subsubsection{Effective Remedies}

Class treatment can allow a PILO to make better use of its limited resources by helping to make any resulting injunctive relief more effective. In particular, class certification helps to ensure that

64 See City of Burlington v. Dague, 505 U.S. 557 (1992).

65 An important qualification relates to post-decree monitoring fees, for which noncontingent hourly rates are reasonable rather than structurally under- compensatory, because the plaintiffs' fee eligibility has already been established. See Maureen Carroll, Fee-Shifting Statutes and Compensation for Risk, 95 Indiana L.J. 1021, 1063 (2020). To the extent that class treatment facilitates post-decree monitoring fees, fee-shifting statutes can provide a firm with a financial incentive to seek class certification in an injunction-only case that it is otherwise inclined to pursue.

66 This choice would be the rational one because the expected value of each hour spent on a fee-shifting case, which must be discounted for the risk of ineligibility for fees, is less than the expected value of a billable hour, which will be billed to the client regardless of the outcome.

67 Presumably, if a deep-pocketed client requested that an injunction-only case be brought as a class action and agreed to pay for the attorneys' work on behalf of the class, a rational, profit-motivated law firm would be inclined to accept. It is unlikely, however, that law firms receive many such requests.

68 See supra note 5 and accompanying text.

69 See Laura Beth Nielsen \& Catherine R. Albiston, The Organization of Public Interest Practice: 1975-2004, 84 N. C. L. REv. 1591, 1605-06 (2006) (estimating that "there were a little over 1,000 PILOs [public interest law organizations] operating in the United States in 2000"). Though significant in absolute numbers, the more than 1,000 PILOs represent only a small slice of the U.S. market for legal services, which contains more than 15,000 private law firms that employ five or more lawyers each. See George P. Baker \& Rachel Parkin, The Changing Structure of the Legal Services Industry and the Careers of Lawyers, 84 N.C. L. REv. 1635, 1650 fig. 2a (2006).

70 In a recent study, only 25 percent of a random sample of nonprofit public interest law firms received federal legal aid funding. Catherine R. Albiston \& Laura Beth Nielsen, Funding the Cause: How Public Interest Law Organizations Fund Their Activities and Why It Matters for Social Change, 39 LaW \& Soc. Inquiry 62, 78 (2014).

$7^{1} \quad$ Id. at 76 .

$7^{2}$ See Deborah L. Rhode, Public Interest Law: The Movement at Midlife, 6o Stan. L. Rev. 2027, 2053-62 (2008). 
the remedy will address not merely the injuries suffered by a few affected individuals, but the underlying violation itself.

\subsubsection{Curing an Injury versus Curing the Violation}

Class treatment has particular value when there is a gap between the remedy needed to cure an individual's injury and the remedy needed to cure the defendant's violation. Consider, for example, the racial segregation of K-12 (i.e., elementary and secondary) public schools. On the one hand, the Supreme Court has held that a formerly segregated school district has "the affirmative duty to take whatever steps might be necessary to convert to a unitary system in which racial discrimination would be eliminated root and branch." ${ }^{73}$ As this language makes clear, the remedy for such a violation is a broad one. On the other hand, the Supreme Court has also held that an injunction "must ... be limited to the inadequacy that produced the injury in fact that the plaintiff has established."74 In a nonclass case, depending on the specifics of the plaintiff s injury and the evidence presented, the remedy that flows from this principle might be a narrow one. ${ }^{75}$

This gap had consequences for the desegregation litigation of the 1950s and 1960s. After students in nonclass cases proved that their school district engaged in large-scale racial discrimination, some courts would issue an injunction that required only particular school assignments for the particular plaintiff students. ${ }^{76}$ That type of remedy would leave the underlying violation essentially intact; certainly, it would fall short of the command to eliminate racial discrimination "root and branch."77 From the perspective of a public interest law organization making case selection decisions, this potential for an essentially meaningless remedy would make a nonclass desegregation lawsuit a questionable use of its resources. ${ }^{7^{8}}$

This possibility - that the injunction available to an individual plaintiff will not address the root cause of that plaintiffs injury - is not specific to desegregation lawsuits. Consider a nonclass case seeking to enjoin the National Security Agency's metadata program, under which the NSA "indiscriminately collect[ed] the telephone call records of millions of Americans."79 Two plaintiffs successfully challenged the program, obtaining a preliminary injunction against it. That relief, however, required only that the NSA stop collecting the data from those two claimants' telephone accounts; it allowed the data collection to continue for millions of others. ${ }^{80} \mathrm{~A}$ public interest law organization might not be eager to invest a substantial amount of its limited resources in order to obtain such a meager result.

By matching the identity of the plaintiffs to the extent of the defendant's violation, an injunction-only class action can close this gap between individualized and comprehensive remedies. Indeed, the drafters of Rule $23(\mathrm{~b})(2)$ had this gap firmly in mind, and they perceived

73 Green v. Cty. Sch. Bd. of New Kent Cty., Va., 391 U.S. 430, 437-38 (1968).

74 Lewis v. Casey, 518 U.S. 343, 357 (1996); see also Califano v. Yamasaki, 442 U.S. 682, 702 (1979) (“[T]he scope of injunctive relief is dictated by the extent of the violation established.").

75 See Maureen Carroll, Class Actions, Indivisibility, and Rule 23(b)(2), 99 B.U. L. Rev. 59, 79 (2019).

76 David Marcus, Flawed but Noble: Desegregation Litigation and Its Implications for the Modern Class Action, 63 FLA. L. Rev. 657, 680 (2011).

77 See id. at 680

$7^{8}$ Cf. Maureen Carroll, Class Action Myopia, 65 Duke L.J. 843, 859 (2016) (noting that this remedial approach "could result in integration only after multiple lawsuits and great expense"). From the perspective of the student, this remedy might be unattractive as well. See David Marcus, Flawed but Noble: Desegregation Litigation and Its Implications for the Modern Class Action, 63 FLA. L. Rev. 657, 680 n.134 (2011) ("[I]f successful, a plaintiff would find him- or herself the sole black student in an all-white school - hardly a pleasant prospect for the student").

79 Klayman v. Obama, 142 F. Supp. 3d 172, 176 (D.D.C. 2015). $\quad 80 \quad$ Id. at 198. 
a serious need for the class action rule to address it. ${ }^{81}$ In recent years, courts have become more comfortable with issuing injunctions that extend beyond the plaintiff in a nonclass case. ${ }^{82}$ Courts and scholars have questioned that remedial approach, ${ }^{83}$ however, and it can be difficult to predict whether a court will issue a broad injunction in any particular nonclass case. ${ }^{8}$ From the perspective of a public interest law organization, a class action can thus offer a better value proposition than a nonclass case - or series of nonclass cases - that might leave the violation unchecked even after the plaintiffs prevail.

\subsubsection{Providing Net Benefits versus Shifting the Harm}

Beyond leaving a violation unchecked, a nonclass case might end up making things worse, at least from other claimants' point of view. As explained below, class treatment can help to assure a public interest law organization that an injunction-only case will produce net benefits, as opposed to merely redistributing the harm among fewer members of the affected group.

The potential absence of a net benefit is of particular concern in litigation against underfunded public institutions or agencies. Consider, for example, a recent lawsuit against the US Department of Veterans Affairs (VA), which provides health care and other benefits for military veterans. The plaintiffs sought an injunction compelling the VA to reduce the lengthy delays that now characterize certain stages of its benefit determinations. ${ }^{85}$ If a nonclass claim of this type were to succeed, the most straightforward way to reduce the delay facing the individual claimant would be to move her to the front of the queue. That "line-jumping" relief would speed things up for that individual, but it would slow things down for everyone who had been in line ahead of her. ${ }^{86}$ A public interest law organization might not want to put its limited resources toward obtaining that result. By contrast, a class-wide remedy could address the root cause of the delays, benefiting all of the affected veterans at once. ${ }^{87}$

Class treatment facilitates injunctive relief that reduces rather than reallocates harm in other types of litigation as well. Consider, for example, recent litigation seeking to improve mental health services in Alabama prisons. ${ }^{88}$ There, the district court determined that it would be "impossible to grant any meaningful relief on this claim without granting it on a class-wide basis." 89 The court reasoned that an order granting relief only to a single prisoner "would rob Peter to pay Paul; the court would be playing a zero-sum game, shifting mental-health care

${ }_{81}$ See David Marcus, Flawed but Noble: Desegregation Litigation and Its Implications for the Modern Class Action, 63 FLA. L. ReV. 657, 700-01 (2011).

82 See Samuel L. Bray, Multiple Chancellors: Reforming the National Injunction, 131 Harv. L. Rev. 417, 418 (2017) (discussing this trend). These injunctions may be motivated, at least in part, by the remedial gap discussed in the text. See, e.g., City of Chicago v. Sessions, No. 17 C 5720, 2017 WL 4572208, at "3 (N.D. Ill. Oct. 13, 2017) (refusing to stay the nationwide aspect of a preliminary injunction in a nonclass case because doing so would "allow the Attorney General to impose what this Court has ruled are likely unconstitutional conditions across a number of jurisdictions”).

83 See Maureen Carroll, Class Actions, Indivisibility, and Rule 23(b)(2), 99 B.U. L. Rev. 59, 105 n.263 (2019) (collecting decisions and commentary critical of injunctions that extend beyond the plaintiff).

84 See Maureen Carroll, Aggregation for Me, but Not for Thee: The Rise of Common Claims in Non-Class Litigation, 36 Cardozo L. Rev. 2017, 2034 (2015) (discussing district courts' de facto discretion over this aspect of remedial scope).

85 Godsey v. Wilkie, No. 17-4361, 2019 WL 2462344 (Vet. App. June 13, 2019). Specifically, veterans face “a multiyear wait before [a VA regional office] even looks at an appealed case to determine whether further development and/or adjudication is warranted before certifying and transferring a case to the Board [of Veteran's Appeals].” Id. at *12.

86 See id. at "13 (noting the "undesirable consequence of line-jumping associated with individual petitions alleging delay").

87 Id. at "10 (" $[\mathrm{P}]$ etitions alleging systemic delay are "best addressed in the class-action context, where the court could consider class-wide relief that would inure to all similarly situated claimants.") (quoting Ebanks v. Shulkin, 877 F.3d 1037, 1039-40 (Fed. Cir. 2017)).

88 Braggs v. Dunn, 317 F.R.D. 634 (M.D. Ala. 2016). $\quad{ }^{89} \quad$ Id. at 668. 
resources from one prisoner to another." $9{ }^{\circ}$ By contrast, a class-wide injunction could expand the resources available to the prisoners as a group - for example, by requiring the prison to hire additional psychiatrists. ${ }^{91}$ By facilitating systemic relief, class treatment can make this type of case more attractive to a public interest law organization at the outset, and it can expand the group of people served by the litigation when it concludes.

\subsubsection{Merits Decisions}

Sometimes, a public interest law organization will bring a lawsuit for purposes of generating binding legal precedent on a particular issue..$^{92}$ Even when that is not the case, a firm operating in the "private attorney general" model will generally not want a case to be dismissed before it can be adjudicated or settled. Unless post-filing events have made clear that any decision on the merits would be unfavorable, such a firm would likely view a non-merits dismissal (and the resulting absence of any resolution or relief) as a waste of the resources it has invested in the litigation.

Class treatment can help to prevent that waste of resources, especially in injunction-only cases. Consider dismissals for lack of justiciability. In order for a federal court to have the power to decide a case, "an actual controversy must be extant at all stages of review, not merely at the time the complaint is filed." 93 In particular, if the plaintiff seeks to enjoin particular conduct by the defendant, she must show that she personally faces the threat of injury from that conduct not merely that the conduct harmed her in the past, nor even that it continues to harm or threaten harm to others. ${ }^{94}$

Class certification changes the mootness analysis, shifting the focus from the named plaintiff (as an individual) to the plaintiff class (as a group). A named plaintiff must generally have a live claim at the time of certification, but once the class has been certified, the class representative can continue to litigate on behalf of the class even if her personal claim becomes moot. ${ }^{95}$ At that point, the plaintiffs can avoid a dismissal for mootness so long other members of the class have live claims for injunctive relief. ${ }^{96}$ Consider a plaintiff who files a nonclass case alleging that her employer has an unlawful employment policy. If she leaves her job while the case is still pending, she cannot continue to seek an injunction against the policy. ${ }^{97}$ Instead, because her now-former employer's policy no longer threatens to harm her, her claim for injunctive relief will be dismissed as moot..$^{9}$ If that same plaintiff obtains class certification, however, she can continue to seek a class-wide injunction against the challenged policy even if she later changes jobs. ${ }^{99}$

90 Id. Moreover, the court doubted that a truly individual remedy could be crafted at all: "Although the court could order, for example, that a particular prisoner who currently requires psychiatric care be seen by a psychiatrist, it cannot order that adequate staffing be provided to the extent necessary to address any one particular prisoner's mental-health care needs as they develop in the future." Id.

$91 \quad I d$.

92 Cf. Pamela S. Karlan, Disarming the Private Attorney General, 2003 U. ILL. L. Rev. 183, 201 (2003) ("The creation of binding precedents is a beneficial byproduct of litigation A private attorney general whose activities produce precedent is thus in some important ways more effective than a private attorney general whose activities produce only local change.").

93 Preiser v. Newkirk, 422 U.S. 395, 401 (1975).

94 See City of Los Angeles v. Lyons, 461 U.S. 95, 101-02, 109 (1983).

95 See Sosna v. Iowa, 419 U.S. 393, 402 \& n.11 (1975).

${ }_{96} \mathrm{Id}$. at 402 . If the class representative's claim has become moot, the court might revisit the question whether she will adequately represent the class. See, e.g., DL v. D.C., 860 F.3d 713, 726 (D.C. Cir. 2017).

97 See Arizonans for Official English v. Arizona, 520 U.S. 43, 72 (1997). ${ }_{98}^{8}$ Id.

99 Cf. id. (emphasizing that the plaintiff did not sue on behalf of a class). 
Different plaintiffs will react differently to the mooting of their individual claims. For example, someone who brings a case for purely self-interested reasons might not especially care whether others remain subject to a policy that no longer affects her. Presumably, however, a public interest law organization (and any client who made it through the PILO's screening process) would be very concerned about the policy remaining in effect. ${ }^{100}$ Class treatment allows the PILO to continue the fight, building on the resources it has already invested instead of having to start over.

Mootness is an omnipresent concern in nonclass cases, but it looms especially large for PILOs that represent certain types of plaintiffs, such as public school students or incarcerated persons. ${ }^{101}$ A student might graduate or move to a different school district, or a defendant might release or transfer an incarcerated person to a different facility, before the litigation ends. In these types of cases, using class certification as a bulwark against mootness is not so much desirable as critical. $^{102}$

Class treatment can help a PILO to avoid other barriers to merits decisions as well. For example, the Individuals with Disabilities Education Act (IDEA) requires a claimant to exhaust her administrative remedies before bringing her claim to court. ${ }^{103}$ An IDEA claimant's failure to exhaust normally results in dismissal of the case. If the claimant alleges "systemic" violations of the IDEA, however, some courts will allow the litigation to continue in spite of the failure to exhaust. ${ }^{104}$ Although some courts have applied this exception in nonclass cases, ${ }^{105}$ others have treated it as a "class action exception," applicable to class plaintiffs only. ${ }^{106}$

Consider a PILO that becomes aware of a widespread, systemic IDEA violation. If the exception described above is unavailable, the PILO will be able to seek relief only on behalf of those who have exhausted their administrative remedies with respect to the violation. It might find that none of the potential claimants have done so, or that those who have done so represent a mere fraction of those affected. Moreover, the PILO might lack the resources to shepherd the affected individuals through the administrative process. By contrast, in courts that recognize this exception, class treatment can enable the PILO to represent every member of the affected group, even without undertaking individualized, resource-intensive representation of multiple claimants in administrative proceedings.

100 In the context of standing to seek injunctive relief, the Supreme Court has assumed that a plaintiff categorically lacks a "personal stake in the outcome" if she is no longer subject to the conduct she seeks to enjoin. See, e.g., City of Los Angeles v. Lyons, 461 U.S. 95, 101 (1983). That assumption strikes me as incorrect. Under the doctrine as it currently stands, however, class treatment offers a second-best approach to the "personal stake" problem that Lyons and cases like it have addressed.

101 Maureen Carroll, Aggregation for Me, but Not for Thee: The Rise of Common Claims in Non-Class Litigation, 36 Cardozo L. Rev. 2017, 2037 (2015).

${ }_{102}$ See id. at 2037-38. Still, such cases will not uniformly suffer mootness dismissals in the absence of class treatment, especially if brought on behalf of an organizational plaintiff or multiple individuals. See id.

103 See 20 U.S.C. $\int \mathbb{S} 1415(\mathrm{i})(2)(\mathrm{A}), 1415(\mathrm{l})$.

104 See Doe v. Arizona Dep't of Educ., 111 F.3d 678, 681 (9th Cir. 1997) (collecting cases in which "several courts have recognized that IDEA claims raising 'systemic' or 'structural' allegations may not need to be administratively exhausted”). But see Parent/Profl Advocacy League v. City of Springfield, Massachusetts, 934 F.3d 13, 27 (1st Cir. 2019) (noting that "[o]ther circuits have defined an exception to the IDEA's exhaustion rule for 'systemic' suits," but declining to decide whether to recognize such an exception); Jamie S. v. Milwaukee Pub. Sch., 668 F.3d 481, 494 (7th Cir. 2012) ("[W]e neither accept nor reject the Ninth Circuit's reasoning in Doe [v. Arizona Department of Education, 111 F.3d at 678.]”).

105 See, e.g., Heldman v. Sobol, 962 F.2d 148 (2d Cir.1992).

106 J.S. ex rel. N.S. v. Attica Cent. Sch., 386 F.3d 107, 113 (2d Cir. 2004); Jamie S. v. Milwaukee Bd. of Sch. Directors, No. o1-C-928, 2012 WL 3600231, at ${ }_{4}$ (E.D. Wis. Aug. 20, 2012). 


\subsubsection{Claimant Participation}

In cases involving injunctive relief, the court and the litigants will often have a great deal of work to do even after a finding of liability has been made. After the liability determination comes the remedy stage, where the shaping of an injunction can require choices among different approaches to curing the defendant's violation. Moreover, even after the court has issued an injunction, its enforcement can require ongoing attention to the defendant's conduct.

Over the past few decades, public interest law organizations in the United States have occasionally been criticized on a number of grounds related to the remedy and enforcement stages of injunction-only cases. One such criticism relates to public interest lawyers privileging their own views over those of the people they represent, especially with regard to the content of injunctive relief. In desegregation cases, for example, some firms drew criticism for continuing to prioritize racial integration as a remedy even after African American parents made clear that they would have preferred improvements to their neighborhood schools. ${ }^{107}$

Another criticism relates to PILOs disengaging after obtaining a favorable judicial decision, regardless of the extent to which the decision has actually affected the reality on the ground. ${ }^{108}$ Merely assuming that a defendant will obey an injunction, without further verification or monitoring, can render a victory hollow. Indeed, some have argued that resistance to the implementation of judicial relief severely constrains the ability of litigation to bring about meaningful social change. ${ }^{109}$

By facilitating claimant participation in the shaping and enforcement of injunctive relief, class treatment offers the potential for mitigating these concerns. Not only does class certification make it easier for members of the affected group to intervene, ${ }^{110}$ but "[l]arge swaths of class action law concern cases in which unnamed class members may monitor the proceedings, oversee class counsel, retain individual counsel, and help mold the ultimate relief in the case." ${ }^{111}$ The court has discretion whether to order class-wide certification notice, ${ }^{112}$ but absent class members must receive notice of any proposed settlement, ${ }^{113}$ and those who disagree with the proposed injunctive relief will have the opportunity to lodge an objection with the court. ${ }^{114}$ Perhaps most important, "[a] favorable judgment in a class action embraces absent class members and gives them authority to enforce its terms." 115

Subjectively, some public interest lawyers might not appreciate all of these participationpromoting aspects of class treatment, but they offer important safeguards against attorney domineering and insensitivity to affected communities. With regard to remedial choices, the airing of intraclass disagreements can produce an injunction more responsive to the views of the claimant group. With regard to remedial implementation, the expansion of enforcement authority can help to ensure that gains made in litigation will translate into changed conditions on the ground. Each of these effects can improve a public interest law organization's (abstract) return on its (concrete) investment in the case.

107 See Derrick A. Bell, Jr., Serving Two Masters: Integration Ideals and Client Interests in School Desegregation Litigation, 85 YALE L.J. 470 (1976).

108 See Scott L. Cummings, Empirical Studies of Law and Social Change: What Is the Field? What Are the Questions?, 2013 WIS. L. REV. 171, 199-200 (2013) (discussing this critique).

109 See, e.g., Gerald N. Rosenberg, The Hollow Hope (1991).

11 See Robert G. Bone, The Misguided Search for Class Unity, 82 Geo. Wash. L. Rev. 651, 703 n.222 (2014); see also Fed. R. Civ. P. $23($ d)(1)(B)(iii).

11 Elizabeth J. Cabraser \& Samuel Issacharoff, The Participatory Class Action, 92 N.Y.U. L. Rev. 846, 849 (2017).

112 Fed. R. Civ. P. 23(c)(2)(A). $\quad{ }^{113} \quad$ Fed. R. Civ. P. 23(e)(1)(B). ${ }^{114} \quad$ Fed. R. Civ. P. 23(e)(5)(A).

115 Maureen Carroll, Aggregation for Me, but Not for Thee: The Rise of Common Claims in Non-Class Litigation, 36 Cardozo L. ReV. 2017, 2038 (2015). 


\subsection{CONCLUSION}

This chapter has explored the ways in which injunction-only class actions promote access to counsel. Courts and other decision-makers would do well to keep these benefits in mind, especially when considering steps that would affect the availability of class certification under Rule $23(\mathrm{~b})(2)$.

The history of the rulemaking process shows some success on that front. In 2001, for example, the Advisory Committee proposed making some type of certification notice mandatory in class actions certified under Rule $23(\mathrm{~b})(2) .{ }^{116}$ The proposal reflected, in part, the claimantparticipation interests discussed above. In response to the proposal, public interest law organizations argued that the costs of notice would reduce their ability to bring class actions, thereby reducing the number of claimants they would be able to serve. ${ }^{117}$ The Advisory Committee modified the proposal, and as noted previously, the rule now gives courts discretion whether to require certification notice for a Rule 23 (b)(2) class. ${ }^{118}$ The Committee noted that this approach was "meant to strike a fair balance between the competing concerns." 119 Whatever the merits of the balance the Committee ultimately struck, it showed a commendable sensitivity to the potential impact on access to counsel.

Congress has not always demonstrated that same sensitivity. In 1996, for example, it adopted a set of restrictions on recipients of federal legal aid funding, including the prohibition on "initiat[ing] or participat[ing] in a class action suit." ${ }^{20}$ Lawmakers who supported the prohibition argued that LSC had become focused on promoting a radical liberal agenda rather than serving disadvantaged individuals' legal needs. ${ }^{121}$ Even assuming the validity of that critique, ${ }^{122}$ however, prohibiting class actions throws the baby out with the bathwater. Because a class action offers an efficient mechanism for serving many disadvantaged individuals' needs at once, the prohibition reduces funded organizations' capacity to serve those individuals. ${ }^{123}$ It is past time for

${ }_{116}$ Robert H. Klonoff, Class Actions for Monetary Relief Under Rule 23(b)(1)(A) and (b)(1)(B): Does Due Process Require Notice and Opt-Out Rights?, 82 Geo. Wash. L. Rev. 798, 828-29 (2014). The change would have applied to class actions certified under Rule $23(\mathrm{~b})(\mathrm{1})(\mathrm{A})$ and (B) as well. Id.

117 Id. at 829 .

118 Fed. R. Civ. P. 23 (c)(2)(A). As noted previously, unlike with notice of class certification, courts must order notice of a proposed class settlement. See Fed. R. Civ. P. $23(\mathrm{e})(1)(\mathrm{B})$.

11 Robert H. Klonoff, Class Actions for Monetary Relief Under Rule 23(b)(1)(A) and (b)(1)(B): Does Due Process Require Notice and Opt-Out Rights?, 82 Geo. Wash. L. Rev. 798, 829 (2014) (quoting the minutes of an Advisory Committee meeting held in May 2002); see also Fed. R. Civ. P. 23 - Advisory Committee Note to 2003 Amendments ("The court may decide not to direct notice after balancing the risk that notice costs may deter the pursuit of class relief against the benefits of notice.").

120 See Omnibus Consolidated Rescissions and Appropriations Act of 1996, PL 104-134, April 26, 1996, 110 Stat 1321; see also supra note 5 and accompanying text.

${ }^{121}$ See Mauricio Vivero, From "Renegade" Agency to Institution of Justice: The Transformation of Legal Services Corporation, 29 Fordham URB. L.J. 1323, 1329-33 (2002)(discussing the history of the LSC restrictions); see also Alan Houseman \& Linda E. Perle, Securing Equal Justice for All: A Brief History of Civil Legal Assistance in the United STATES 36 (2018) (“[T]he Congressional majority was determined to redefine the role of federally funded legal services by refocusing legal services advocacy away from law reform, lobbying, policy advocacy, and impact litigation and toward basic representation of individual clients.").

${ }^{122}$ But see Mauricio Vivero, From "Renegade" Agency to Institution of Justice: The Transformation of Legal Services Corporation, 29 FORdham URB. L.J. 1323, 1329 (2002) (explaining that "LSC statistics on annual caseloads contradict this view").

123 See David Luban, Taking Out the Adversary: The Assault on Progressive Public-Interest Lawyers, 91 CaL. L. REV. 209, $224(2003)$ (noting that "the vast majority of cases that legal-services lawyers turn down will never be brought by anyone," and thus "the [LSC] restrictions ensure that entire subgroups of low-income people will never be heard in the legal system”). 
this restriction to be removed, so that federally funded legal aid organizations can do their jobs more efficiently and effectively. ${ }^{124}$

As for the Supreme Court, it wrote in 2011 that Rule 23(b)(2) "does not require that class members be given notice and opt-out rights, presumably because it is thought (rightly or wrongly) that notice has no purpose when the class is mandatory, and that depriving people of their right to sue in this manner complies with the Due Process Clause." ${ }^{25}$ In light of the accesspromoting effects discussed above, it would be unfortunate if the Court continued to flirt with this idea that mandatory Rule 23 (b)(2) classes are unconstitutional. Absent class members' due process rights should not be weaponized against them.

This chapter has focused on the plaintiff-side benefits of injunction-only class actions, but of course, such actions also have downsides for claimants and their counsel. Foremost among these is preclusion, because a certified class action constrains further litigation on behalf of absent class members, regardless of whether they win or lose. ${ }^{126}$ In addition, because plaintiffs must affirmatively demonstrate that they comply with the requirements of Rule 23 (a) and (b), law firms (including public interest law organizations) must devote time and resources to obtaining class certification. ${ }^{127}$ For all of the reasons discussed above, however, the benefits of injunction-only class actions will often be worth the costs.

124 Cf. Catherine Albiston, Su Li, \& Laura Beth Nielsen, Public Interest Law Organizations and the Two-Tier System of Access to Justice in the United States, 42 LaW \& Social Inguiry 990, 1017 (2017) ("[S]ystemic reform and rule change may be a more efficient and cost-effective means of assisting [PILOs'] disadvantaged clients than serial litigation of cases one at a time.").

125 Wal-Mart Stores, Inc. v. Dukes, 564 U.S. 338, 363 (2011).

${ }_{126}$ Due in large part to these preclusive effects, one commentator has argued that class treatment in injunction-only cases benefits the defendant and not the plaintiffs, and that attorneys for the plaintiffs should therefore bring such cases solely on a nonclass basis. See Timothy Wilton, The Class Action in Social Reform Litigation: In Whose Interest?, 63 B.U. L. REv. 597 (1983).

127 See Wal-Mart Stores, Inc. v. Dukes, 564 U.S. 338, 350 (2011) ("A party seeking class certification must affirmatively demonstrate his compliance with the Rule - that is, he must be prepared to prove that there are in fact sufficiently numerous parties, common questions of law or fact, etc."). 